\title{
Miénk itt a tér!
}

\section{- avagy új könyvtári közösségi és szolgáltatási terek kialakítása és müködése}

\author{
Liskáné Fóthy Zsuzsanna, Istók Anna
}

\begin{abstract}
"Az első hely az otthonunk, a második a munkahelyünk, a harmadik pedig
\end{abstract} egy, az elöbbi kettőtől független közösségi tér." (Ray Oldenburg)

\begin{abstract}
A könyvtár mint harmadik hely, kiválóan alkalmas a közösségi kapcsolatok erősitésére, a különböző korú és érdeklődésű emberek találkozására egy helyi társadalomban. Szórakozás, kikapcsolódás, közösségi együttlét, tudásmegosztás - a harmadik hely nélkülözhetetlen ismérvei, melyek mind megtalálhatók egy jól müködö könyvtárban. A közösségi tér funkció a Gödöllöi Városi Könyvtárban is nagy hangsúlyt kapott az elmúlt években, elötérbe kerültek a szabadidős, kikapcsolódási és szórakozási funkciók a hagyományos könyvtári szolgáltatások mellett. Ugyanakkor a közösségi tér (harmadik hely) feladatát csak akkor tudja jól ellátni egy könyvtár, ha a térre-szolgáltatásra-gyüjteményre mint egymástól elválaszthatatlan egységre gondolunk, és mindegyikre kellö figyelmet fordítunk. Egyik sem müködik a másik nélkül, jelen írásunkban ennek a hármas egységnek a müködtetését kívánjuk bemutatni, kiemelten kezelve a tér funkciót.
\end{abstract}

Tárgyszavak: városi könyvtár, kulturális szolgáltatás, közösségi tér, közösségfejlesztés

Könyvtárunk épülete bár még csak húsz éves lesz 2022-ben, de a tereket folyamatosan megújítjuk az olvasói igényeknek megfelelően. Korábban népszerű könyvtári szolgáltatások erodálódása maga után vonta az azokkal kapcsolatos könyvtári terek látogatottságának kihasználatlanságát. Csak néhány példa az elmúlt évekből: az információkeresési szokások átalakulása következtében jócskán megcsappant az irodalomkutatások, az olvasótermi gyüjtemény használatának száma, aminek következtében jelenlegi olvasótermünk csak vegetál. A korábban legforgalmasabb Infohíd látogatottsága az otthoni számítógép- és internet-előfizetések általánossá válásával szinte nullára csökkent. De vannak pozitív változások is, illetve újonnan keletkező igények, melyek szintén térátalakításra ösztönzik a könyvtárakat: az ifjúsági célcsoport megjelenése, a közösségi klubok iránti igény a mi könyvtárunkban is jelentős változásokat okozott.
- 2018-tól kezdve folyamatos építkezésben vagyunk, az olvasói igényeknek megfelelően szüntetünk meg részlegeket, állományrészeket, és alakítunk ki újakat:

- 2018-ban a KamaszHíd ifjúsági részleg került átadásra.

- 2019-ben a Zöld Udvar és Terasz Könyvtár nyílt meg.

- 2020-ban Infotér nevet és új funkciót kapott a korábbi folyóirat-olvasónk, és lett belőle közösségi irodaként is használatos közösségi tér.

- 2022-ben tervezzük a Közösségi alkotótér kialakítását a hozzá kapcsolódó új szolgáltatásokkal.

Minden átalakulás előtt előzetes igényfelmérés, illetve alapos teljesítménymutatói elemzés is készült. Stratégiai céljainkkal összhangban alakítottuk ki rövidtávú terveinket, és vittük véghez a változásokat, melyek legfontosabb mozgatóru-

Liskáné Fóthy, Zs., Istók, A. Miénk itt a tér! - avagy új könyvtári közösségi és szolgáltatási terek kialakítása és múködése, Tudományos és Műszaki Tájékoztatás, 69(1), p. 6-14, 2022. https://doi.org/10.3311/tmt.13133 
gója az, hogy mire van szükségük a használóknak. Az olvasók manapság nem szolgáltatásokat keresnek, hanem élményeket, olyan kulturális tartalmakat, melyeknek értékét nekünk kell megnövelni más szolgáltatásokkal, kiegészítő termékekkel. A mi feladatunk az, hogy a kulturális termékből élményt varázsoljunk számára, és ebben fontos szerepet kap a térélmény is. (1. ábra)

Az élménykereséshez hozzátartozik a térélmény is, az otthonérzés, a szimbólumokkal megnövelt esztétikai látvány, az inspirációra, kreativitásra ösztönző tér. Ennek legékesebb példája a gödöllői Kamaszhíd, mely a felnőtt és gyermekkönyvtárat összekötő hídon kapott helyet, egyfajta szimbolikus átjáróként a két korosztály között.

A térszimbolikát számos esetben fel tudjuk használni egy könyvtárban, gondoljunk csak egy játékos labirintusra a gyermekrészlegen, ami felfedezésre csábít, vagy egy kényelmes, párnás olvasókuckóra, ami egyszemélyes szigetként jelent kikapcsolódást és elvonulást a zsúfolt mindennapokból. A sort hosszan lehetne folytatni; a következőkben a gödöllői könyvtárban alkalmazott térélményeket és a hozzájuk kapcsolt szolgáltatásokat mutatjuk be. A közösségi terek kialakításánál mindig is elsődleges szempont volt számunkra a kiszolgálandó célcsoport igénye, valamint a közösség fejlesztése klubok, programok, kisközösségek kialakításával, működtetésével, ez szinte minden esetben megelőzte magát a tényleges fejlesztést.

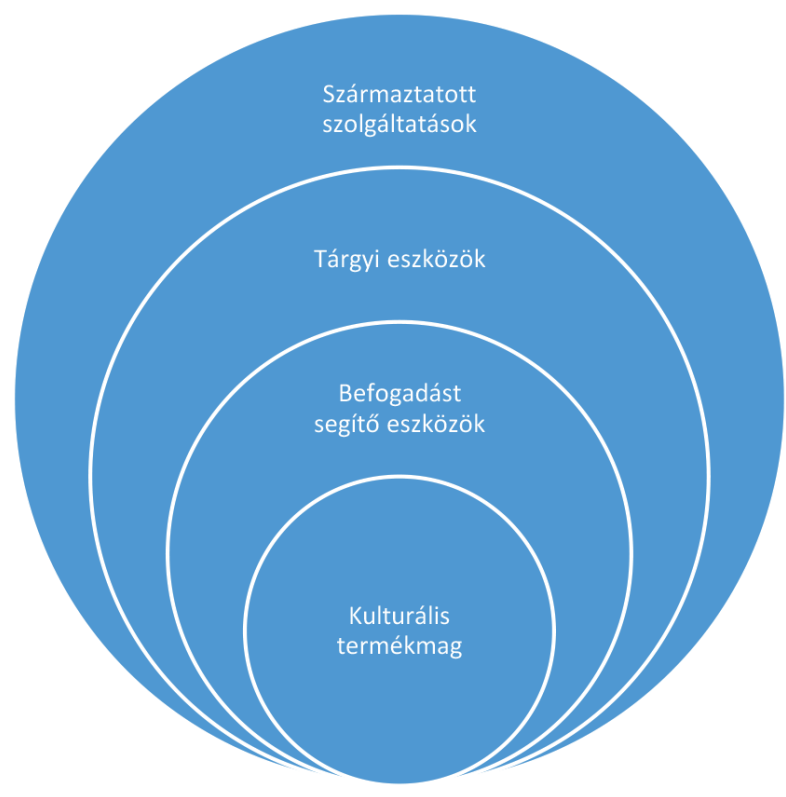

1. ábra A kulturális termékhagyma

\section{KAMASZHÍD}

\section{Elözmények}

Könyvtárunk 2002-es megnyitásakor nem volt külön ifjúsági részleg, az ifjúsági könyvek beleolvadtak a gyerekkönyvtári állományba, és kifejezetten kamaszoknak szóló programok, klubok, szolgáltatások sem voltak. A 2010-es évek elején az igényeknek megfelelően elindult a kamasz célcsoport felé a nyitás, a szolgáltatásfejlesztésnek ebben a célcsoportban az igazán nagy lendületet a 2015-ös Olvasók diadala digitális olvasóvetélkedő adta meg. Ettől kezdve felgyorsultak az események, sorra alakultak meg az ifjúsági klubok, kialakult a tiniknek szóló könyvállomány, ifjúsági programokat szerveztünk. És természetesen felmerült az igény egy önálló részlegre is, mely a funkcióját vesztett Infohídon kapott helyett. A Kamaszhíd kialakítása során tervezőpályázatot hirdettünk, ahol a fiatalok konkrét ötletekkel szolgáltak a megvalósítással kapcsolatban. (2. ábra)

\section{Térélmények}

2018-ban adtuk át az elkészült Kamaszhidat, az új ifjúsági részlegünket a közönség számára. A Kamaszhíd tervezésekor a következő térélményeket kívántuk megvalósítani (3. ábra):

- Híd: szimbolikus átmenet a felnőtt- és gyermekkor között.

- Magány: távol minden más részlegtől, bekuckózós hely.

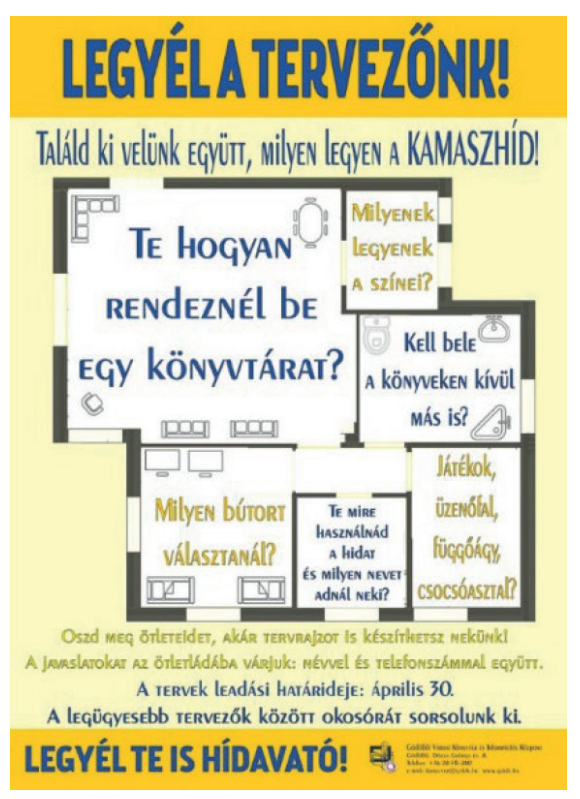

2. ábra A Kamaszhíd tervező pályázat plakátja 


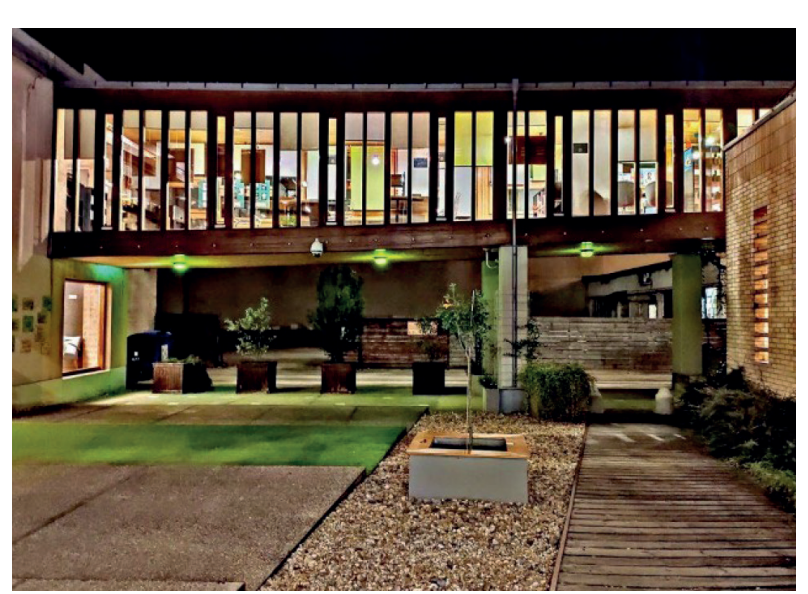

3. ábra Kamaszhíd

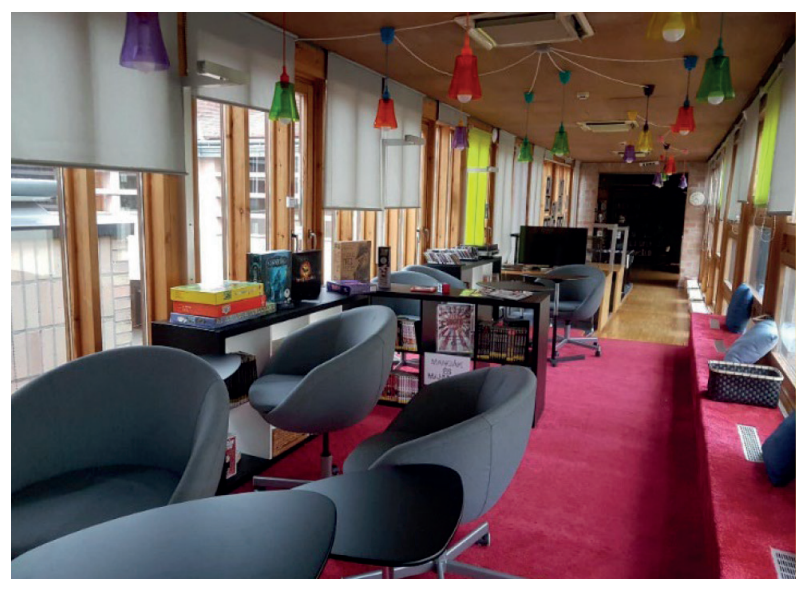

4. ábra Kamaszhíd belülről

Játékosság: könyvek mellett a hídon képregények, mangák, társasjátékok, lemezek. A bútorok szabadon variálhatók, átrendezhetők.

Otthonosság: süppedő szőnyegek, vidám színek, kényelmes bútorok, üzenőfal.

Közösségi élmény: csocsóasztal, X-boksz, szobabicikli, mobil bútorok.

Tanulás: munkaasztalok, laptop, rajztábla.

\section{Szolgáltatások}

A hozzá kapcsolt szolgáltatásoknál a legfontosabb a közösségépítés volt, így alapvetően klubok és programok kialakítása, működtetése előzte meg a Kamaszhíd átadását. (4. ábra)

- Kisközösségek: Pusztítók diák írókör, Papírolvasók olvasókör, Médiaklub, Anime klub, War game, Angol társalgási klub, Sakk kör működik jelenleg is a könyvtárban.

- Alkotótér és kiállítóhely - kreatív írókurzus, médiakurzus mellett a híd maga a fiatal múvészek galériájaként is funkcionál.
- Programok: helyi ifjúsági alkotók bemutatkozása, népszerú ifjúsági írók, vloggerek, influenszerek meghívása.

- Háromnapos kreatív író/olvasó tábor. már négy éve hagyományosan nyáron szervezzük az összes kamasz csoport részvételével.

- Tematikus napok: japán nap (2020), görög nap (2021).

- Kamaszoknak szóló könyvtári órák.

- Éjszaka a könyvtárban: közösségépítő alkalmak.

\section{Gyújtemény}

- Könyvsú-go: az ifjúsági könyvek elrendezése

- kreatív módon történt. A Könyvsú-go interaktív könyvválasztó oldal (https://konyvsu-go.gvkik. hu/) alapján, 14 témába szétosztva kerültek a kötetek nagyon látványos módon. (5. ábra)

- 14 téma: a fiatalokat leginkább érintő, akár tabutémák is kerültek a polcokra, a tematikus elnevezések könyvcímek lettek.

- Könyvválasztó oldal elektronikusan: a nagy könyvturmix a Könyvsú-go, melyhez könyvtári óra is társul, ahol megtanulhatják a diákok a felépítését, az adatok feltöltését pedig Iskolai
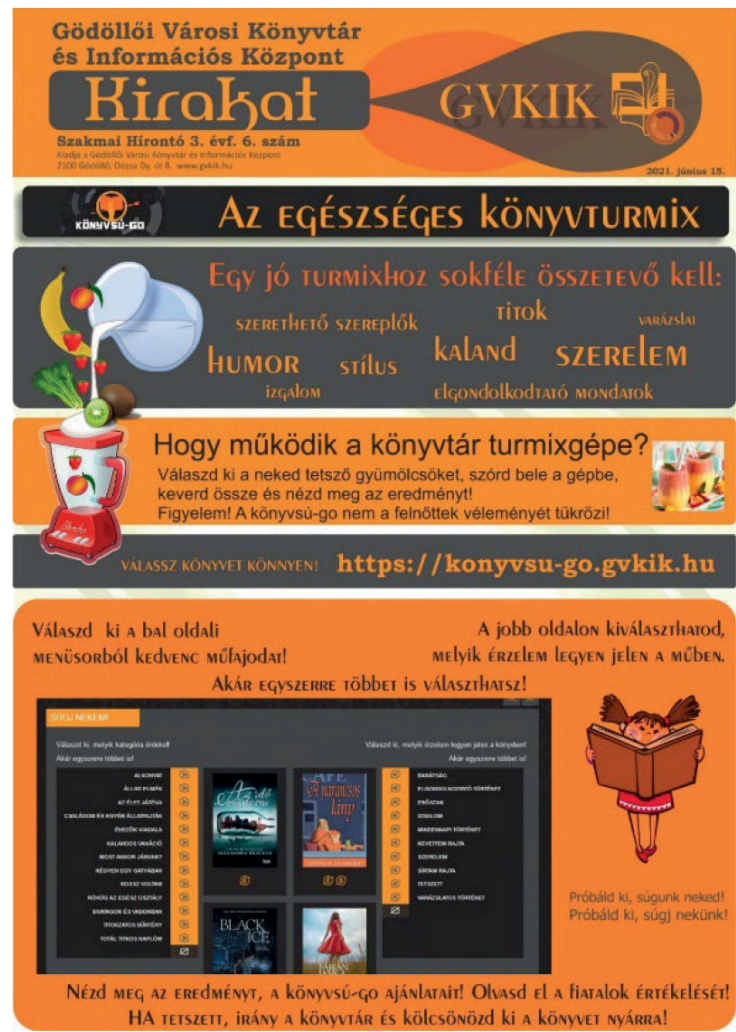

5. ábra A Könyvsú-go hirdetése a gödöllői könyvtár szakmai hírlevelében, a Kirakatban 
Közösségi Szolgálat keretein belül is végezhetik. Az adatbázisban jelenleg kb. 500 ifjúsági könyvből lehet válogatni műfajok, érzelmek szerint. A Könyvsú-go különlegessége, hogy a véleményeket fiatalok írják, tehát saját korosztály ajánlata alapján lehet olvasnivalót keresni benne.

- Idegen nyelvü regények: a legnépszerübb ifjúsági kötetek angol nyelven is elérhetők a Kamaszhídon.

- Mangák, képregények, animék: a gyüjtemény kibővítése megindult olvasói igények alapján. A gyűjteményrészhez Képregényküldetés címmel könyvtári óra is tartozik, illetve Anime klub működik már több éve a könyvtárban.

- New Adult: a kamaszkori olvasmányt követő tematikus válogatás helye nem a Kamaszhídon van, de szóróanyag hívja fel a fiatalok figyelmét arra, ha kinőttek a kamaszkorból, merre találnak olvasnivalót.

- Moly polcok: Tinipolc, New Adult polc a moly.hu-n.

\section{ZÖLD KÖNYVTÁR}

\section{Elözmények}

Összhangban a város stratégiai céljaival a 2010-es évek vége felé könyvtárunk is a zöld szemlélet felé fordult. Új stratégiai célként emeltük be a zöld könyvtári elvek érvényesitését működésünkbe, megalakult a minőségirányítási tevékenység keretében a Zöld Munkacsoport, és ezzel párhuzamosan megindult a zöld programok szervezése, a munkatervünk zöldesítése is. (A témával részletesen itt foglalkoztunk: Istók Anna - Tóth Gabriella: Zöld városban zöld könyvtár, Megjelent: Könyvtári Figyelő 2021/2. számában 239-246. oldal).

Számos kisebb program, szolgáltatás mellett önkormányzati támogatással nagyobb beruházásra is sor került 2019-ben, a Zöld Könyvtár Évében: kialakítottuk Terasz Könyvtárunkat és a Zöld Udvart is, ezáltal nemcsak a stratégiai céljainkat, a zöld szemléletformálást indítottuk útjára, hanem újabb közösségi tereket is nyertünk.

\section{Térélmények}

2019 a Zöld Könyvtár Éve volt intézményünkben, ez nemcsak beruházásokat jelentett, hanem megindultak a környezetvédelemmel kapcsolatos szolgáltatásfejlesztések, programok is. Átalakult a korábban használaton kívüli terasz, és szerves részévé vált a földszinti tereknek. A Zöld könyvtárhoz kapcsolt térélmények a következők voltak:

- Kertélmény. A belváros betonszívében üde zöld folt vagyunk, a Teraszkönyvtáron virágfal választja el az olvasókat a forgalmas úttól. Kávézó, újságok, virág egyvelege. (6. ábra)

- Pihenés: a belső Zöld udvaron napozóágyak, napvitorla, múfú, pingpongasztal várja a kikapcsolódásra vágyókat.

- Artjáró: a Zöld udvar egyben zöld kiállitótér is gödöllői múvészek számára, továbbá udvari koncertek, irodalmi estek hangulatos helyszíne, ami a kreativitás élményét adja át.

- Tündérkert: újrahasznosított anyagokból épült a legkisebbeknek - a varázslat élménye.

- Olvasók kertjeés Olvasókfája-közösségiélmény - minden Könyves Vasárnap új olvasók nevei kerülnek fel a fára.

\section{Szolgáltatások}

A zöld beruházásokkal párhuzamosan indult meg a szolgáltatásfejlesztés (7. ábra):

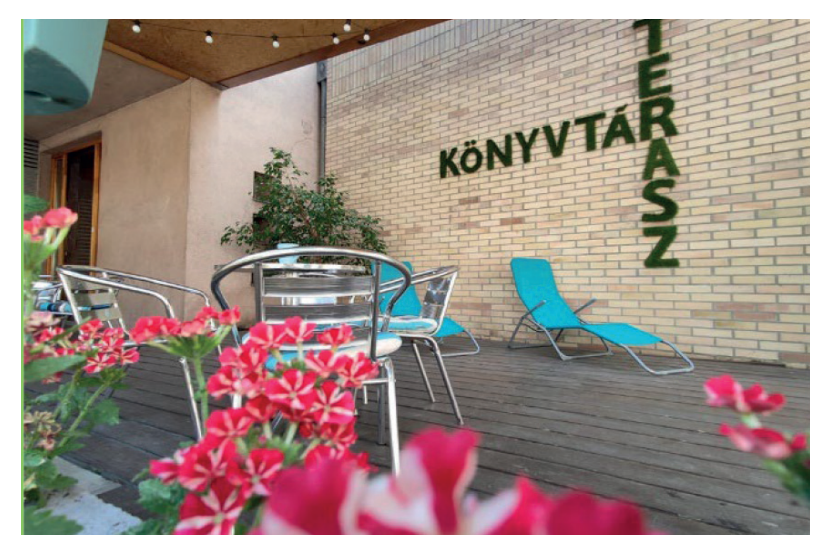

6. ábra Terasz Könyvtár

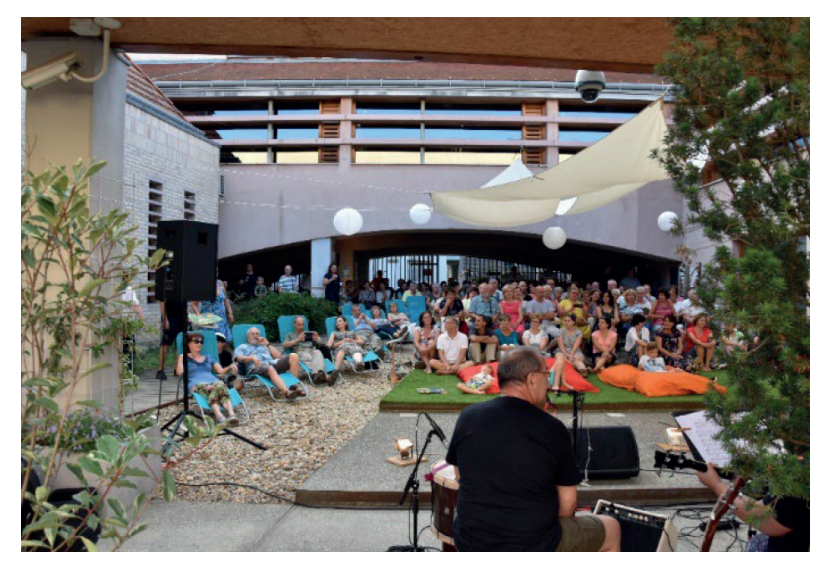

7. ábra Zöld udvar egy nyáresti koncerttel 
- Udvari programok: klubok, táborok, estek fontos helyszínévé vált az udvar, melynek a járvány miatti korlátozás további lendületet adott.

- Zöld könyvtári órák: a fenntarthatóság és környezetvédelem témakörében számos könyvtári foglalkozást bezöldítettünk a legkisebb korosztálytól kezdve a középiskolásokig.

- Szemléletformálás: zöld programok, zöld kommandó nemcsak olvasóknak, hanem a munkatársak számára is.

- Zöld honlap: külön menüpontban gyűjtjük zöld szolgáltatásainkat, de a távszolgáltatások kibővítése is stratégiai cél.

- Paperless office: ennek maradéktalan megvalósítására törekszünk évek óta, számos előrelépés történt már ez ügyben: közös drive, felhőben tárolt anyagok, elektronikus szóróanyagok preferálása a print anyagokkal szemben, elektronikus kommunikáció támogatása, távszolgáltatások fejlesztése.

\section{Gyüjtemény}

- Zöld polcok: gyermek és felnőtt könyvtárban külön gyüjteményrészt alakítottunk ki, melyekből folyamatos könyvajánlók készülnek a honlapra.

- Molyos zöld polc: a könyvek a moly.hu-n tematikus polcra kerültek, így virtuálisan látszik, mik vannak a gyüjteményben.

- Tündérkert mesepolc: a varázslatos minikerthez tündéres mesékből állítottunk össze egy polcot, mely fizikailag (jó időben) és elektronikusan (moly.hu) is elérhető. (8. ábra)

- Zöld könyvajánlók: folyamatosan kerülnek fel a honlapra a zöld programajánlók mellett a gyưjteményünkbe kerülő zöld könyvek ajánlói.

- Zöld pecsét: a zöld gyújtemény a katalógusban is lelőhely kódot kapott, a könyvekben egy szép zöld pecsét jelöli a könyv fizikai helyét.

\section{INFOTÉR}

\section{Előzmények}

Az olvasói igények folyamatos változásban vannak, korábban hangsúlyos könyvtári szolgáltatások tűntek el, és jelentek meg újak. Az egyik ilyen formálódó változás a home office-ban dolgozók, a közösségi irodát igénylők megjelenése volt könyvtárunkban. Egyre inkább azt tapasztaltuk,
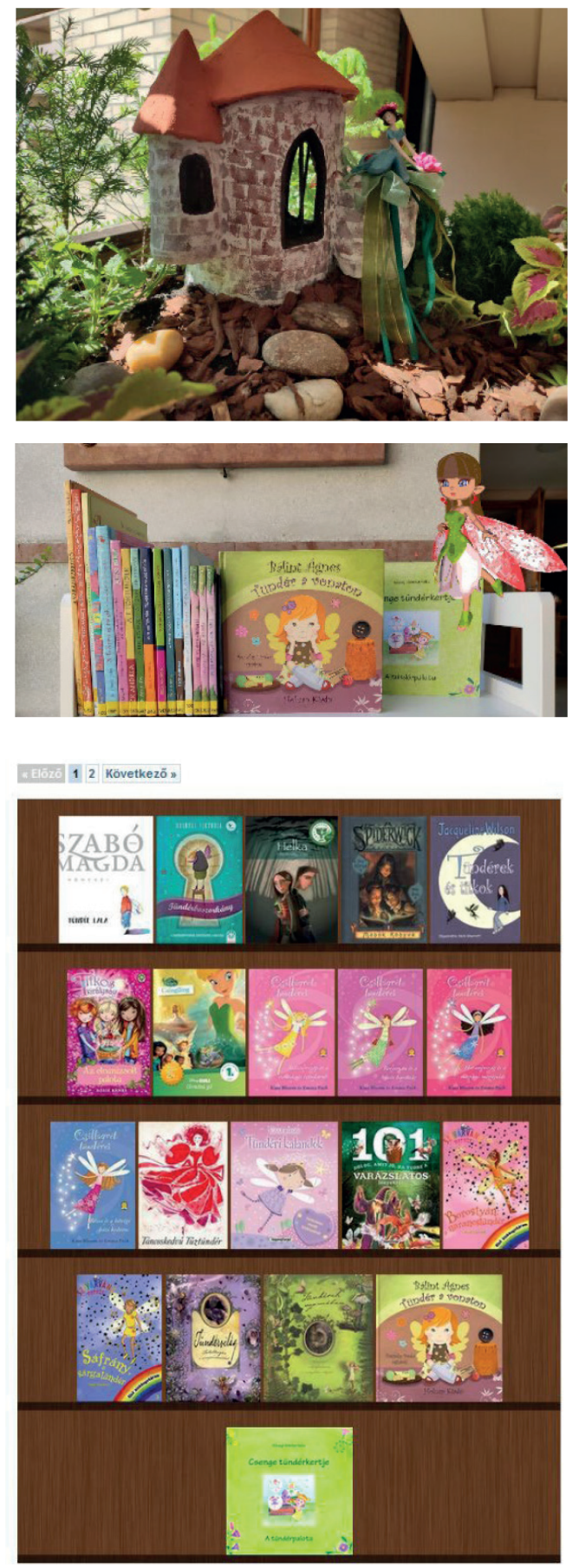

8. ábra Tündéres mesék a moly.hu-n a gödöllői könyvtár polcai között és a valódi Tündérkert a könyvtár udvarán a könyvekkel

hogy szükség van egy olyan közösségi találkozóhelyre, ahol az emberek munkamegbeszélés, tanulás, dolgozás céljából tudják használni a tereinket. Igényfelmérés alapján szűkítettük le a lehetőségeinket 2019-ben és terveztük át a korábbi folyóirat-olvasónkat, megtartva korábbi funkciókat, de kiegészítve újabbakkal is. (9. ábra) 


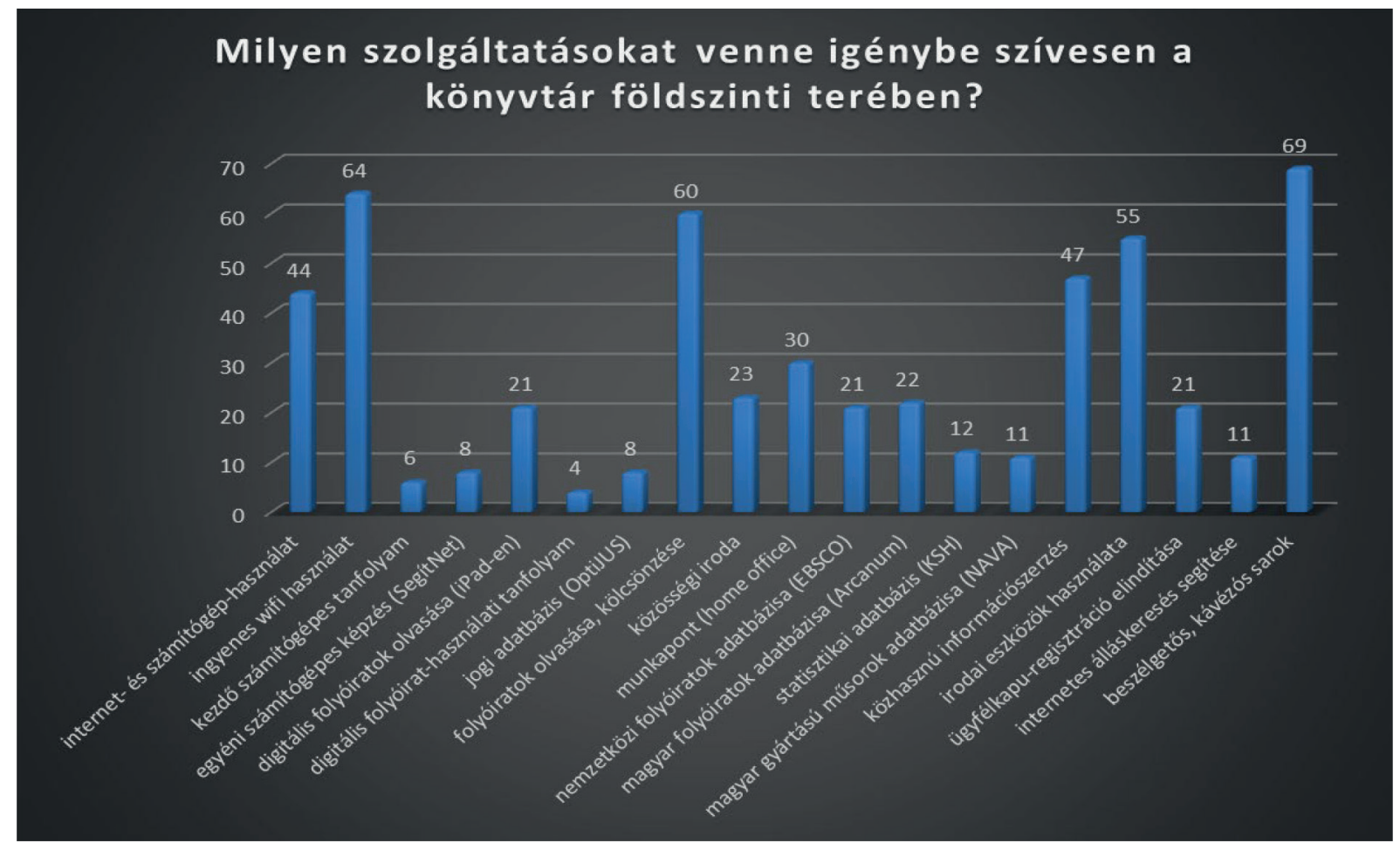

9. ábra Infotér előzetes igényfelmérés

\section{Térélmények}

Infoterünk megújulására 2020 év elején került sor. A korábbi folyóirat-olvasó és kávézó nem csak új, mobil bútorokat kapott, hanem számos új szolgáltatást is telepítettünk a térbe, valamint a helyiség design elemekkel is bővült. (10. ábra)

- A mindent egy helyen élménye: a tagsági vagy regisztrációs jegy nélkül, szabadon látogatható közösségi tér egy agora, az intézmény és a város központi helyisége.

- Tárgyaló: a helyiség kisebb tárgyalásokra is alkalmas mobil bútoraival.

- Munkaállomások: minden, ami a közösségi irodához szükséges, itt megtalálható.

- Nappali: a munka mellett kényelmes kuckó a lazításhoz, újságokkal, könyvekkel, társasjátékokkal és a Mi újság? kávézó kínálatával.

- Akadálymentesség és átjárhatóság: regisztráció nélkül használható, a legnyitottabb terület a könyvtárban, melynek öt bejárata is van.

- Múvészet: a város kultikus kiállítóhelye is itt található, a helyiség összenyitható a szomszédos rendezvényteremmel, így alkalmas nagy rendezvények lebonyolítására éppúgy, mint meghittebb összejövetelekre.

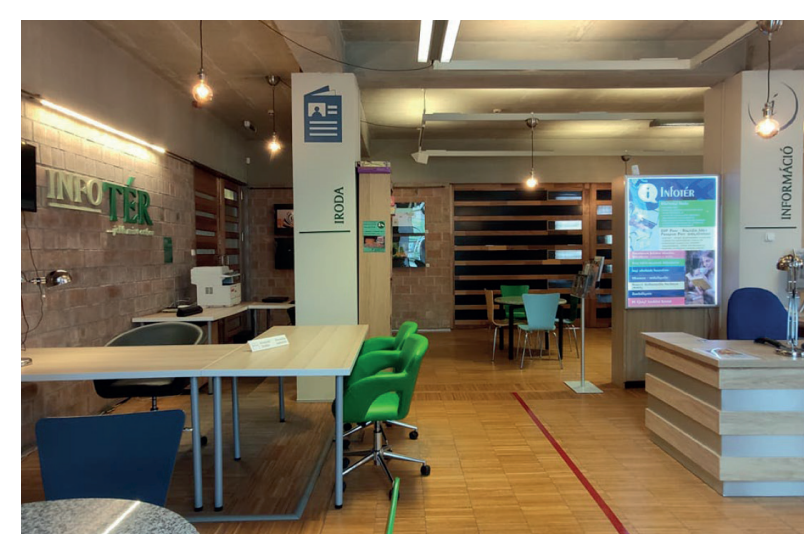

10. ábra Infotér, Közösségi iroda

\section{Szolgáltatások}

- Információ: minden, ami a könyvtárral kapcsolatos és közérdekű információszolgáltatás, lehetőség van itt is beiratkozásra, a járvány idején pedig oltási regisztrációs pontként is üzemel.

- Közösségi iroda: munkaállomások, laptopok, irodai eszközök, wifi.

- DJP program: csoportos és egyéni számítógépes tanfolyamok, segítség ügyfélkapu használatához.

- Folyóirat-olvasó: digitális és hagyományos megjelenésű folyóiratok széles választéka található itt. (11. ábra)

- Adatbázisok: Jogi, Observer, NAVA.

- Mi Újság? Irodalmi Kávézó 


\section{Gyưjtemény (12. ábra)}

- New Adult regények kerültek az Infotérbe, mint egy teljesen új állományrész.

- Magazinok, napilapok: a szakfolyóiratok nem itt találhatók.

- Társasjátékok: új szolgáltatás a társasjáték kölcsönzés és a havi egyszeri társasjáték klub is.

- Dokumix. könyvek, CD-k, DVD-k, újságok egy helyen adott témában.

- Kávézó könyvei: tematikus válogatás a kávézóban a könyvtár állományából, melyet időrőlidőre cserélünk.

\section{MAKERSPACE}

\section{Elözmények}

Könyvtárunkban a járvány előtt 19 múködő kisközösség munkálkodott, jobbára önkéntes olvasók, könyvtárosok vezetésével. Ez a szám kismértékben csökkent a korlátozások miatt, 15 megmaradt klubunk azonban így is a legfontosabb célcsoport számunkra: kezdve a kreatív nagyiktól, az alkotó fiatalokon át a játékos kedvű családokig. Az alkotás

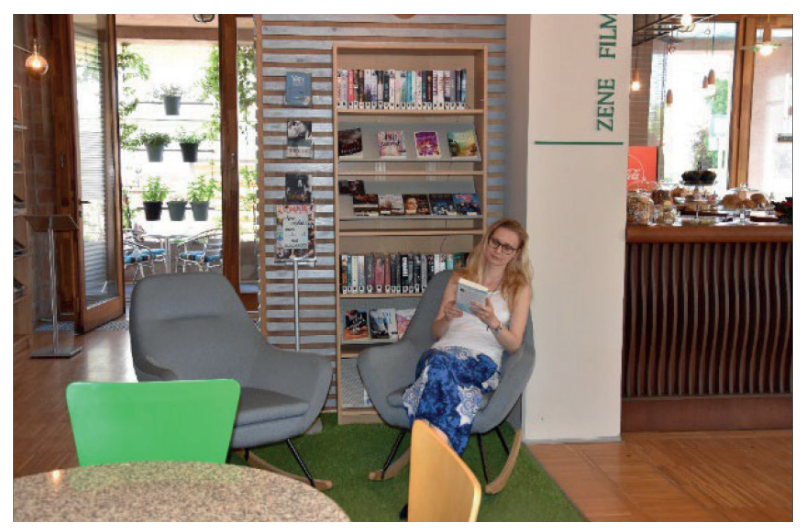

11. ábra Infotér, Folyóirat-olvasó

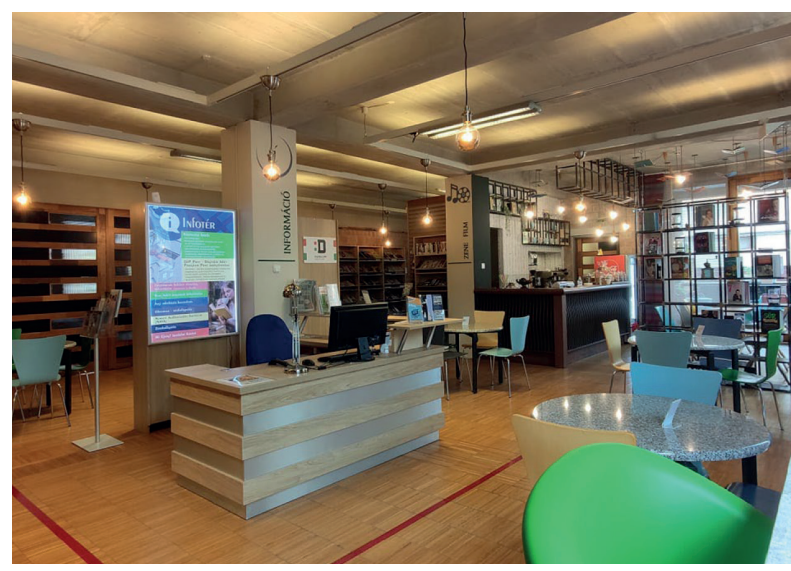

12. ábra Infotér, kávézó és könyvtáros munkapult iránti igény egyre népszerűbb a szabadidő eltöltésében, mint harmadik hely könyvtárunk kiemelten támogatandó feladatának érzi ezt. Ehhez azonban újabb és újabb terekre van szükségünk, így a 2021es és 22-es évet ennek kialakítására szenteljük.

\section{Térélmények}

Könyvtárunkban, hasonlóan más intézményekhez, a CD és DVD állomány kölcsönzése évek óta mélyrepülésben van. A 2020-as karantén még tovább erősítette ezt a negatív folyamatot, hiszen egyre népszerúbbé váltak az otthonokban a streaming szolgáltatók, így ma már az audiovizuális állomány további fejlesztése nem indokolt. Épületünkben a MásArc zenei és filmrészleg kihasználatlanságát kell megoldanunk, melyre 2021-ben születtek meg a tervek. A részleg a földszinti területen helyezkedik el önálló bejárattal, így alkalmas arra, hogy közösségi térré váljon. Alapvetően makerspace szolgáltatásokat fogunk a jövőben telepíteni ide, a beruházást pályázati forrásból valósítjuk meg 2022-ben, de vannak már tevékenységek, melyeket önerőből el tudtunk indítani 2021 végén. Zenei könyvtárosunk a témában továbbképzésen vett részt, és további önkéntesek bevonására is sor került. A tervek szerint az új alkotótér a következő élményekkel várja a látogatókat (13. ábra):

- Inspiráció élménye: a hely szerves folytatása az Artjáró udvarnak és kiállítótér is egyben - az inspiráció élményét maga a hely múvészi jellege is adja: a MásArc zenei és filmrészleg.

- Egyben, mégis külön: mobil bútorokkal az egész tér belakható, a funkciónak megfelelően átrendezhető.

- Kirakat: nagy üvegfelületű ablakokban elhelyezett szolgáltatások önmagukat reklámozzák.

- Színek és formák: a tér berendezése kreativitásra ösztönöz.

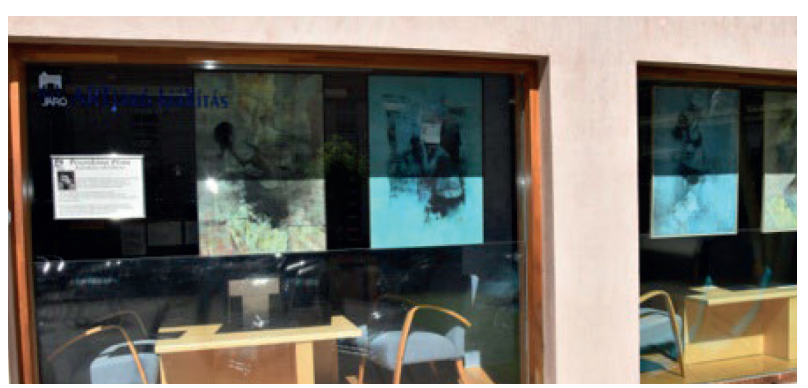

13. ábra Artjáró, a Zöld udvar kiállítótere 


\section{Szolgáltatások}

- Lego játszótér: könyvtári órák helyszíne is lesz a jövőben.

- Könyvkötészet: kreatív kézműves foglalkozások indulnak majd önkéntes olvasó és könyvtáros vezetésével.

- Varrómúhely: klubok, zöld könyvtári programok fontos helyszíne lesz.

- Sütisarok: a beépített sütő könyvtári foglalkozások, programok helyszíneként funkcionál majd.

- Rajzasztal

- 3K: Könyv, Kávé, Kötés - új olvasókör indítását tervezzük, mivel igény is mutatkozik rá.

\section{Gyüjtemény}

- Fonaltár. zöld könyvtári szemléletet is szeretnénk megvalósítani az újrahasznosítás jegyében.

- Magtár: szintén a zöld könyvtári szellemben tervezzük.
- Sütisarok: a könyvtár nemcsak könyveket kölcsönöz érvényes olvasójeggyel, hanem számos olyan kreatív, sport stb. eszközt, melyhez szolgáltatásai révén kapcsolódik: pingpongütő, társasjáték, sütiforma stb.

A gödöllői könyvtárnak egyre nagyobb szerepe van a helyi közösségi élet formálásában. Szeretnénk otthonossá varázsolni az épületet, kihasználni a benne rejlő lehetőségeket. A fejlesztések, újítások mindig a látogatók igényei alapján történnek, de törekszünk arra is, hogy ne csak reagáljunk a felmerült igényekre, hanem előre gondolkodó jelleggel kitapogassuk azokat az útvonalakat, melyek felé a fogyasztói figyelem irányul majd a jövőben. A fejlesztések megvalósítása során pedig igyekszünk olyan tematikus élményeket kínálni a látogatóknak, melyek egyszerre hatnak az érzékszervükre és az érzelmeikre. (14. ábra)
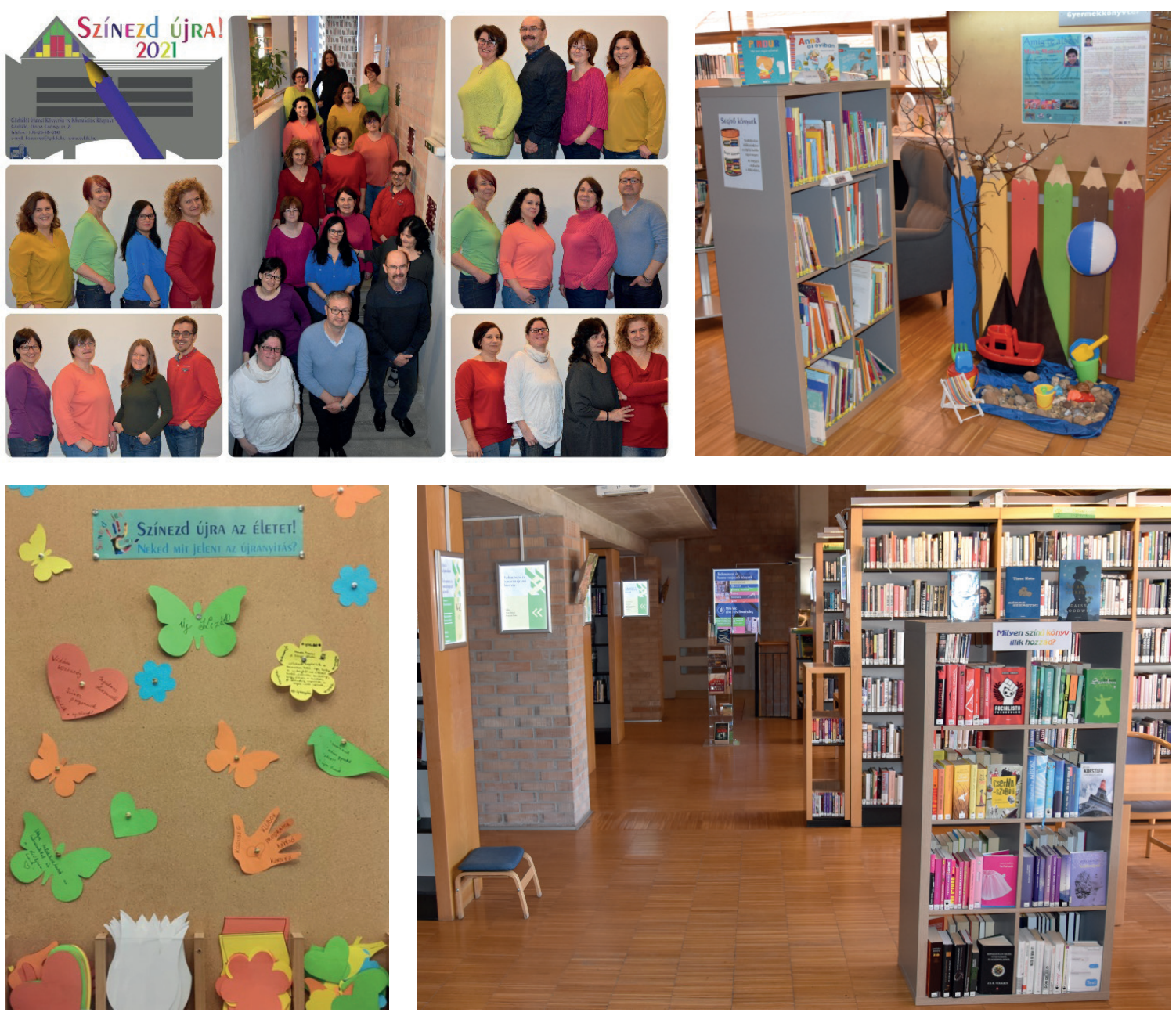

14. ábra Színezd újra! - a 2021-es év tematikája a gödöllői könyvtárban 
Beérkezett: 2022. január 5.

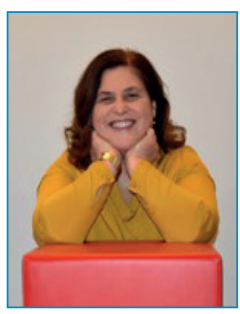

\section{Liskáné Fóthy Zsuzsanna}

igazgató

Gödöllői Városi Könyvtár és Információs Központ

fothy@gvkik.hu

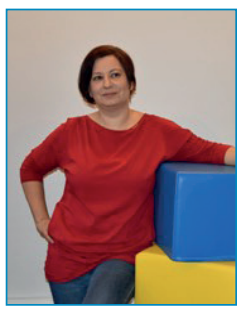

\section{Istók Anna}

igazgatóhelyettes

Gödöllői Városi Könyvtár és Információs Központ

istoka@gvkik.hu 